\title{
Fnstructors in Slisatbematícs
}

PERSONAL NOTES.

Mr. W. C. Brenke, '96, has' becn appointed Atstin Teaching Fellow in Astronomy in Harvard University.

Miss Mary Anderson, '03, is professor of mathematics in the Illinois Woman's College at Jacksonville, I11.

Miss H. Amanda Westhold, '03, is teaching mathematics in the Quincy (Illinois) High School.

Mr. Noah Krapp, '04, is teaching mathematics in the Rock Island (Illinois) High 'School.

Miss Mildred Sonntag, '04, is principal of the Lexington (Illinois) High School.

Miss Maud Patterson, '04, is teaching mathematics and German in the Utbana (Illinois) High School.

Mr. A. R. Crathorne, '98, who has been for several years instructor in mathematics in the University of Wisconsin, is now studying ander Hilbert and Klein at Göttingen.

Mr. G. H. Scott, '96, is professor of mathematics and astronomy in Yankton College, Yankton, S. D.

ERNEST B. LYTLE.

\section{NO'TE TO INSTRUCTORS IN MATHEMATICS.}

By J. E. Gould,

Seattle, Wash.

The following books have been found most useful to instructors and students of high school mathematics. The list is submitted to the instructors in the high schools with a view to assisting them to some extent in the selection of books for the library or for the teacher's private use. An interchange of opinions regarding these and other books will be helpful to all teachers, and suggestions concerning other books of reference will be gladly received by this department.

Number and Its Algebra: Arthur Lefevre; D. C. Heath \& Co.; $\$ 1.25$. A syllabus of lectures on the theory of number and its algebra. The book is very valuable to the teacher and can be read by students advanced in the high school.

Teaching of Elementary Mathematics: D. E. Smith; McMillan Co.; $\$ 1.00$. This book treats of the development of arithmetic, algebra and geometry. It presents the results of the best of mathematical scholarships to be applied in class-room teaching. A good list of books for the teacher is also given.

Algebra (two voltumes): Chrystal; Macmillan Co.; $\$ 7.50$. This is probably the most reliable and complete work on the stubject within the grasp of the high school student. It is recognized as a standard book of reference.

The Number System of Algebra: H. B. Fine; D. C. Ifeath \& Co..; $\$ 1.00$. In this text the number system is treated theoretically and historically. The exposition of the number concept, the negative, the irrational and the imaginary is valuable. 
The Study and Difficulties of Malhematics: 1) Morgan; The Open Court Co.; $\$ 1.25$. A series of excellent lectures on many important points in the subject.

Elementary Practical Mathematics: Frank Castle; MacMillan Co.; 60 cents. As a source of practical problems and illustration of graphic methods in algebra and arithmetic, this book is very uscful.

Elements of Applicd Mathomatics: C. M. Jessop; Deighton Bell \& Co.; $\$ 1.25$. Easy applications of mathematics are here presented which give students continual inspiration in the work of real life.

History of Mathematics: W. W. R. Ball; MacMillan Co.; $\$ 3.25$. This is a reliable, brief history of the subject, and an interesting reference book for both teacher and studicnt.

Computation: E. M. Longley; Longmans, Green \& Co.; $\$ 1.00$. This is an account of the chicf methods for contracting and abhreviating arithmetical calculations.

Psychology of Numbers: McI.ellan \& Dcwey; D. Appleton \& Co.; $\$ 1.50$. No teacher of mathematics can afford to be without this book. It carrics the ratio idea of number to an extreme, but it is the clearest and best exposition of the psychology of the subject written by American atthors.

Heath's Mathematical Monographs: D. C. Heath \& Co.; per copy, 10 cents. These are freshly written pamphlets upon the history, thcory, subject matter and methods of tcaching both clemcntary and advanced topics.

Trigonometry: Crockett; American Book Co.; $\$ 1.25$. An excellent textbook in advance of high school work.

The Common Sense of the Exact Sciences: W. K. Clifford; D. Appleton $\&$ Co. $\$ \$ 1.50$. An interesting discussion of the subject, and one which, for the most part, can be easily understood by secondary students.

$\Lambda$ valuable report for the secondary teacher is that of the Committee on the Correlation of Mathematics and Physics in Secondary Schools. This is a part of the proceedings of the Central Association of Science and Mathematics Teachcrs. Copies can be obtained from Mr. E. Marsh Williams, Treasurer High School, LaGrange, Illinois; price 25 cents.

The sccond meeting of the New York section of the Association of Teachers of Mathematics of the Middle States and Maryland was held at the College of the City of New York on Saturday, March fourth. After an address of welcome by President Finley, Prof. Joseph Bowden of Adelphi College, Brooklyn, and Mr. John H. Denbigh of the Morris High School, Manhattan, read papers on "The Graph in Early Algebra." The next subject, "The First Year in Algebra," was introduced by Miss Margaret I. Ingalls of the Girls' High School, Brooklyn, who was followed by Mr. Oscar W. Anthony of the DeWitt Clinton High School, Manhattan. The discussion which followed the formal papers was animated and interesting. 